\section{Skala, metrische}

C. Vidal ${ }^{1}$ und W.-R. Külpmann ${ }^{2}$

${ }^{1}$ Landeskriminalamt Niedersachsen, Dezernat 53 „Chemie“, Hannover, Deutschland

${ }^{2}$ Hannover, Deutschland

Synonym(e) Kardinalskala

Englischer Begriff metric scale
Definition Oberbegriff für Differenzskala ( $\triangleright$ Intervallskala) und Ratio-Skala ( $\triangleright$ Verhältnis-Skala).

\section{Literatur}

DIN 55350, Teil 12 (1989) Begriffe der Qualitätssicherung und Statistik. Merkmalsbezogene Begriffe. Beuth-Verlag, Berlin 